\title{
Occurrence of Cochlodinium fulvescens (Gymnodiniales: Dinophyceae) in the southwestern Gulf of California
}

\author{
Ocurrencia de Cochlodinium fulvescens (Gymnodiniales: Dinophyceae) \\ en el suroeste del Golfo de California \\ Ismael Gárate-Lizárraga ${ }^{1}$
}

\begin{abstract}
${ }^{1}$ Instituto Politécnico Nacional, Centro Interdisciplinario de Ciencias Marinas, Departamento de Plancton y Ecología Marina, Apartado postal 592, La Paz, B.C.S. 23000, México. igarate@ipn.mx

Abstract.- The naked dinoflagellate Cochlodinium fulvescens was rarely observed in Bahía de La Paz since 2008. Sporadic observations were made in 2010 and 2012. The species re-appeared from October 2012 to April 2013. Abundance of $C$. fulvescens ranged from 600 to 45,800 cells $\mathrm{L}^{-1}$ during this period in seawater temperature at $22-27^{\circ} \mathrm{C}$ and salinity of 35.25 35.75. This species appeared as single cells or two-celled chains and co-occurred with Cochlodinium polykrikoides at the end of the bloom. C. fulvescens usually occurs in autumn to spring and C. polykrikoides usually occurs in spring to autumn. The main distinguishing morphological characters between these two species are the relative position of the cingulum and sulcus and the morphology of chloroplasts. This provided reliable identification of live cells. Other Cochlodinium species, such as $C$. faurei, $C$. pulchellum, and $C$. rosaceum were also observed in the bay.
\end{abstract}

Key words: Dinoflagellates, Cochlodinium fulvescens, Cochlodinium polykrikoides, southwestern Gulf of California

\section{INTRODUCTION}

The genus Cochlodinium belongs to the order Gymnodiniales Lemmermann, 1910. Cochlodinium is an unarmored, marine planktonic dinoflagellate with a distinctive spiral-shaped cingulum of 1.5 or more gyres around the cell. Some photosynthetic Cochlodinium species form cell chains. According to the recent worldwide review of marine dinoflagellates (Gómez 2011), there are 35 species of Cochlodinium. Cochlodinium fulvescens Iwataki, Kawami \& Matsuoka, 2007 was recently described as a new species (Iwataki et al. 2007). Taxonomy and distribution of Cochlodinium species have occasionally been studied in Mexico. Twelve species of Cochlodinium have been found in Pacific coastal waters of Mexico (Gárate-Lizárraga et al. 2004, 2009a, b; 2011; Cortés-Lara et al. 2004, Okolodkov \& Gárate-Lizárraga 2006, Morquecho-Escamilla \& Alonso-Rodríguez 2008, Gárate-Lizárraga 2013). In these reports, massive blooms of Cochlodinium polykrikoides Margalef, 1961 have been recorded along the west coast of Mexico (Morales-Blake et al. 2001, Gárate-Lizárraga et al. 2004, 2009b). Cochlodinium fulvescens has been reported in lagoons and bays along the southern Gulf of California (Morquecho-Escamilla \& Alonso-Rodríguez 2008, GárateLizárraga et al. 2009a). Recently, other species of Cochlodinium, including C. convolutum Kofoid \& Swezy, 1921, C. helicoides Lebour, 1925, C. helix Schütt, 1895,
Cochlodinium pulchellum Lebour, 1917, and Cochlodinium virescens Kofoid \& Swezy, 1921, have been recorded for the first time (Gárate-Lizárraga et al. 2011, Gárate-Lizárraga 2012). The purpose of this study was to describe the seasonal occurrence of Cochlodinium fulvescens in Bahía de La Paz, Gulf of California.

\section{Materials AND METHOdS}

Bahía de La Paz is the largest bay on the peninsular side of the Gulf of California. The bay constantly exchanges water with the Gulf of California via a northern and a southern opening (Gómez-Valdés et al. 2003). As part of a continuing toxic or harmful microalgae monitoring program, 56 phytoplankton bottle samples were monthly collected from January 2010 to April 2013 at a fixed sampling station in Bahía de La Paz (Fig. 1), in the State of Baja California Sur $\left(24^{\circ} 212 \mathrm{~N}, 110^{\circ} 312 \mathrm{~W}\right)$. Two-day samplings were performed each month from October 2012 to April 2013. Two horizontal tows, using a $20 \mu \mathrm{m}$ mesh net with $50 \mathrm{~cm}$ diameter, were performed. Samples were immediately fixed with acid Lugol's solution and preserved with $4 \%$ formalin. Live phytoplankton samples were used to identify Cochlodinium species. Cochlodinium cell counts were made in $5 \mathrm{~mL}$ settling chambers under an inverted, phase-contrast microscope (Carl Zeiss, 


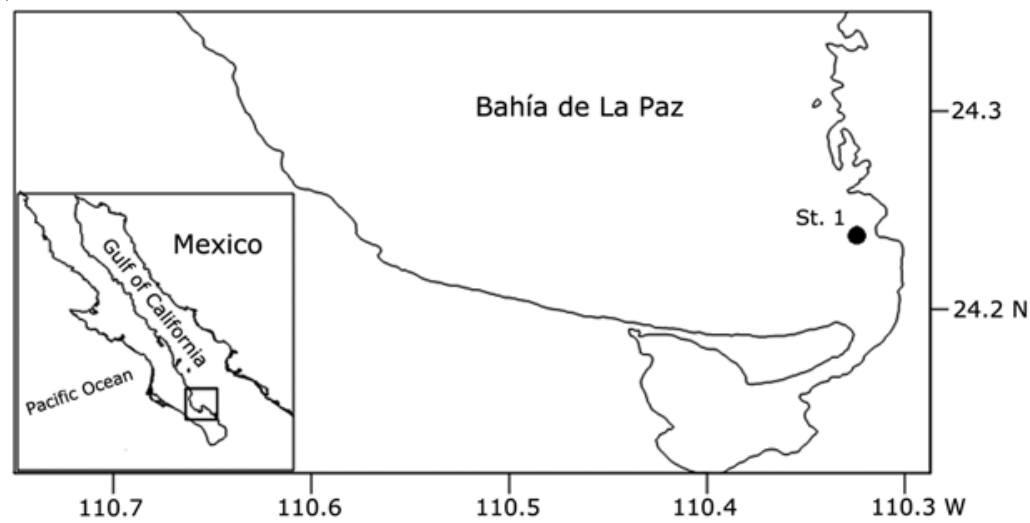

Figure 1. Map of the study area indicating fixed sampling station for microalgae monitoring in Bahía de La Paz / Mapa del área de estudio indicando la estación fija de monitoreo de microalgas en Bahía de La Paz
Oberkochen, Germany) (Utermöhl 1958). Sea surface temperature was recorded with a bucket thermometer. Salinity was measured with a refractometer (Model STX3, Vee Gee Scientific, Kirkland, WA). A compound microscope was used to measure cells and a digital camera (Konus Italia Group, Verona, Italy) was used to record images.

\section{RESUlTS AND DISCUSSION}

During this investigation, only 13 samplings were $C$. fulvescens positive, occurring in a temperature range of $22-27^{\circ} \mathrm{C}$ and salinity of 35.25-35.75 (Table 1). These specimens were either solitary (Figs. 2A-C) or two-cell

Table 1. Abundance of Cochlodinium fulvescens, temperature and salinity data in 13 samplings performed in Bahía de La Paz, from October 2010 through April 2013 / Datos de abundancia de Cochlodinium fulvescens, temperatura y salinidad en 13 muestreos realizados en Bahía de La Paz, de octubre 2010 hasta abril 2013

\begin{tabular}{rccc}
\hline Sampling dates & $\begin{array}{c}\text { Cell abundance } \\
\left(\text { cells L }^{-1}\right)\end{array}$ & $\begin{array}{c}\text { Temperature } \\
\left({ }^{\circ} \mathrm{C}\right)\end{array}$ & Salinity \\
\hline $10 / 16 / 2010$ & $600-1000$ & 27 & - \\
$10 / 21 / 2010$ & $1200-1600$ & 26 & - \\
$12 / 13 / 2010$ & $800-1200$ & 22 & - \\
$04 / 28 / 2011$ & $400-800$ & 25 & - \\
$11 / 24 / 2011$ & $400-800$ & 25 & - \\
$12 / 12 / 2011$ & $800-1400$ & 22 & - \\
$04 / 19 / 2012$ & $800-1000$ & 24 & - \\
$10 / 28-29 / 2012$ & $600-1200$ & 27 & 32.25 \\
$12 / 12-13 / 2012$ & $4000-6600$ & 24 & 35.72 \\
$01 / 16-17 / 2013$ & $7600-10800$ & 23 & 35.42 \\
$02 / 19-20 / 2013$ & $8200-11800$ & 23 & 35.75 \\
$03 / 20-21 / 2013$ & $6400-19800$ & 22 & 35.62 \\
$04 / 24-25 / 2013$ & $27800-45800$ & 24 & 35.68 \\
\hline
\end{tabular}

chains (Figs. 2D-F). No four-cell chains were observed. The specimens fit well with the diagnosis and description of Iwataki et al. (2007). Cells are rounded and ellipsoidal in shape (Figs. 2A-C; D-F). The cingulum encircles the cell twice; the sulcus runs down apart from the cingulum (Figs. 2 B-C). A reddish-orange pigmented body is located at the dorsal side of the epicone (Figs. 2 B-C). The nucleus is spherical and located at the anterior part of the epicone (Fig. 2A). Chloroplasts are granular and distributed along the cingulum and the periphery of the cell. The specimens appear pale yellow. Cells were 32-55 $\mu \mathrm{m}$ long and 25-38 $\mu \mathrm{m}$ wide $(\mathrm{n}=30)$. C. fulvescens became round (Fig. $2 \mathrm{G})$ when preserved with Lugol's solution.

Abundance of $C$. fulvescens was low (400-1600 cells $\mathrm{L}^{-1}$ ) during samplings from 2010 through 2011, reaching peak densities of 4000-6600 cells $\mathrm{L}^{-1}$ in December 2012 (Table 1). An increase in abundance occurred from January through April 2013, reaching moderate densities ranging from 27,800 to 45,800 cells $\mathrm{L}^{-1}$. Other Cochlodinium species were found in net phytoplankton samples from 2013. Three specimens of Cochlodinium faurei Kofoid \& Swezy, 1921 were also found in net phytoplankton samples collected in January 2013 (Fig. $2 \mathrm{H})$. The cells are medium-sized with a sub-ovoid to ellipsoid body. Cells were 60-64 $\mu \mathrm{m}$ long and 35-38 $\mu \mathrm{m}$ wide. The cytoplasm is finely granular, but usually very clear and transparent. This finding is the first record for Bahía de La Paz. Four encysted specimens of $C$. pulchellum Lebour, 1917 were observed in net samples in 24 February 2013. They were small-sized, reaching a total length of 38-44 $\mu \mathrm{m}$, with an asymmetrical fusiform body (Fig. 2 I). This species was also reported earlier in Bahía de La Paz (Gárate-Lizárraga 2011). Two specimens of Cochlodinium rosaceum Kofoid and Swezy, 1921 were found in net phytoplankton samples collected in April 2013; it is a medium-sized species with an ellipsoid, rose- 

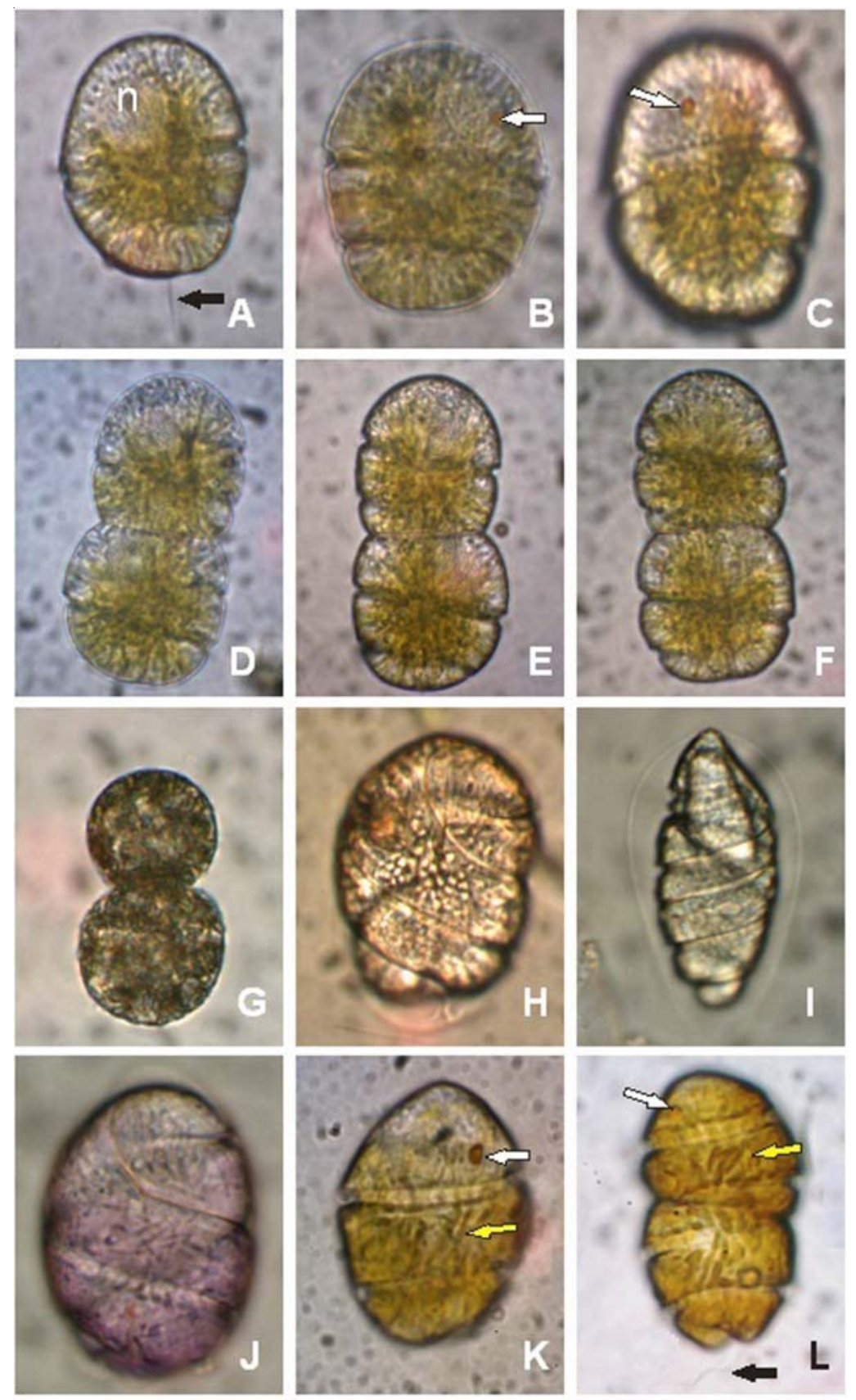

Figure 2. Light microphotographs of Cochlodinium fulvescens, Cochlodinium faurei, Cochlodinium pulchellum, Cochlodinium rosaseum and Cochlodinium polykrikoides from Bahía de La Paz. A-C) Three single cells of Cochlodinium fulvescens showing the nucleus ( $\mathrm{n}$ ), flagellum (black arrow), and stigma (white arrow); D-F) Three two-celled chains of Cochlodinium fulvescens; G) Two-celled chain of Cochlodinium fulvescens fixed with Lugol's solution; H) Specimen of Cochlodinium faurei; I) Hyaline cyst of Cochlodinium pulchellum; J) Specimen of Cochlodinium rosaceum; K) Single cell of Cochlodinium polykrikoides showing stigma (white arrow) and the rod-shaped chloroplasts (yellow arrow); L) Twocell chain of Cochlodinium polykrikoides, showing the reddish orange pigmented body (white arrow), the rod-shaped chloroplasts (yellow arrow), and longitudinal flagellum (black arrow) / Microfotografías de luz de Cochlodinium fulvescens, Cochlodinium faurei, Cochlodinium pulchellum, Cochlodinium rosaseum y Cochlodinium polykrikoides de Bahía de La Paz. A-C) Tres especímenes de Cochlodinium fulvescens mostrando el núcleo ( $\mathrm{n}$ ) el flagelo (flecha negra) y el estigma (flecha blanca); D-F) Tres cadenas de 2 células de Cochlodinium fulvescens; G) Cadena de 2 células de Cochlodinium fulvescens fijada con solución de Lugol; H) Espécimen de Cochlodinium faurei; I) Quiste hialino de Cochlodinium pulchellum; J) Espécimen de Cochlodinium rosaceum; K) Célula solitaria de Cochlodinium polykrikoides mostrando el estigma (flecha blanca) y los cloroplastos acintados (flecha amarilla); L) Cadena de 2 células de Cochlodinium polykrikoides mostrando el estigma de color rojizo naranja (flecha blanca), los cloroplastos en forma de barras (flecha amarilla) y el flagelo longitudinal (flecha negra) 
colored cell (Fig. 2J), and 68-70 $\mu \mathrm{m}$ long and of 32-34 $\mu \mathrm{m}$ wide. Specimens of $C$. rosaceum fit well with the description by Kofoid \& Swezy (1921). This is the first record of this species along the Pacific coast of Mexico.

Cochlodinium fulvescens is a bloom-forming dinoflagellate first found in Tachibana Bay (west Japan), Hurun Bay (South Sumatra), Indonesia (Iwataki et al. 2007), British Columbia (Iwataki et al. 2008), California (Iwataki et al. 2008, Curtiss et al. 2008, Kudela \& Gobler 2012), and the Gulf of California (Morquecho-Escamilla \& AlonsoRodríguez 2008, Gárate-Lizárraga et al. 2009a). Recently C. fulvescens was also reported in the Bahía de Acapulco (Meave del Castillo et al. 2012) and coastal waters of Karachi bordering the northern Arabian Sea (Munir et al. 2012). C. fulvescens was firstly recorded in Bahía de La Paz during a multi-species bloom in June 2008 (GárateLizárraga et al. 2009a) and then in December 2010. Densities of $C$. fulvescens in our study were higher, compared to the report of Gárate-Lizárraga et al. (2009a). However, it was lower than the 380,000 to 490,000 cells L ${ }^{-1}$ reported by Morquecho-Escamilla \& Alonso-Rodríguez (2008) from C. fulvescens blooms in Bahía de Mazatlán $\left(23^{\circ} 11211.83 \mathrm{~N}, 106^{\circ} 26246.23 \mathrm{~W}\right)$.

C. polykrikoides (Figs. 2K-L) is similar to C. fulvescens as both species form cell chains and have a nucleus and an eyespot located in the anterior dorsal part of the cell (Iwataki et al. 2007, Matsuoka et al. 2008). The presence of an eyespot was demonstrated for C. polykrikoides by TEM in Iwataki et al. (2010). A similar position was reported for the phylogenetically related species $C$. fulvescens (Iwataki et al. 2007). C. polykrikoides has numerous rod-shaped chloroplasts which extended longitudinally in healthy cells and were brownish-green in color (Fig. 2L). Meanwhile, C. fulvescens has granular chloroplasts that are distributed along the cingulum and the periphery of the cell. Blooms of C. polykrikoides have become recurrent events in Bahía de La Paz (GárateLizárraga 2013); the most recent occurred from August through October 2013. In samples from October 2012, C. polykrikoides occurred with $C$. fulvescens, with densities of $12800-24,600$ cells $\mathrm{L}^{-1}$ for the former and $1200-1600$ cells $\mathrm{L}^{-1}$ for the latter. The 2 species were previously coupled in the Bahía de La Paz in June 2008 (Gárate-Lizárraga et al. 2009a). There is clear overlap in the preferred temperature range of the 2 species in Bahía de La Paz; C. polykrikoides is common at $20-31{ }^{\circ} \mathrm{C}$ and $C$. fulvescens at $22-27^{\circ} \mathrm{C}$. Our results partly coincide with the work of Munir et al. (2012), with low densities of $C$. fulvescens at $<26^{\circ} \mathrm{C}$ and high densities at $31-32^{\circ} \mathrm{C}$. Kudela \& Gobler (2012) and Howard et al. (2012) state that cells of $C$. fulvescens are present at low temperatures $\left(14-18^{\circ} \mathrm{C}\right)$. Comparing salinity, $C$. fulvescens was common at 35.25-35.75 in the Gulf of California, but Kudela \& Gobler (2012) report that $C$. fulvescens was common at 32.8-33.6 off the coast of California.

In Bahía de La Paz, monitoring of live microalgae specimens that form red tides started in 2000, during a bloom of C. polykrikoides (Gárate-Lizárraga et al. 2004). Since that time, many microalgae bearing a soft cell membrane, such as dinoflagellates and raphidophytes, have been identified (Gárate-Lizárraga et al. 2004, 2009c; Gárate-Lizárraga 2013). Proper identification of several Cochlodinium species in Bahía de La Paz is a good example of the importance of working with fresh samples. The morphology of Cochlodinium species changes during observation under a light microscope. Likewise, cells tend to form a hyaline membrane around the cell or a temporary hyaline cyst (Fig. 2I); otherwise, they would explode. Specimens showing those features were fixed with Lugol's solution and could not be properly identified. Hence, live samples are important in the study of Cochlodinium species and other naked dinoflagellates.

\section{ACKNOWLEDGMENTS}

The projects were funded by grants from the Instituto Politécnico Nacional (SIP-20110139, SIP-20121153, and SIP-20130549). I.G.L is a COFAA and EDI fellow.

\section{LITERATURE CITED}

Cortés-Lara MC, R Cortés-Altamirano \& AP SierraBeltrán. 2004. Presencia de Cochlodinium catenatum (Gymnodinales: Gymnodinaceae) en mareas rojas de Bahía Banderas, Pacífico Mexicano. Revista de Biología Tropical 52(Supl. 1): 35-50.

Curtiss CC, GW Langlois, LB Busse, F Mazzillo \& MW Silver. 2008. The emergence of Cochlodinium along the California Coast (USA). Harmful Algae 7: 337-346.

Gárate-Lizárraga I. 2012. Proliferation of Amphidinium carterae (Gymnodiniales: Gymnodiniaceae) in Bahía de La Paz, Gulf of California. CICIMAR Oceánides 27: 1-13.

Gárate-Lizárraga I. 2013. Bloom of Cochlodinium polykrikoides (Dinophyceae: Gymnodiniales) in Bahía de La Paz, Gulf of California. Marine Pollution Bulletin 67: 217-222.

Gárate-Lizárraga I, DJ López-Cortés, JJ BustillosGuzmán \& FE Hernández-Sandoval. 2004. Blooms of Cochlodinium polykrikoides (Gymnodiniaceae) in the Gulf of California, Mexico. Revista de Biología Tropical 52(Supl. 1): 51-58. 
Gárate-Lizárraga I, CJ Band-Schmidt, F Aguirre-Bahena \& T Grayeb-del Álamo. 2009a. A multi-species microalgae bloom in Bahía de La Paz, Gulf of California, Mexico (June 2008). CICIMAR Oceánides 24(1): 1-15.

Gárate-Lizárraga I, JA Díaz-Ortiz, B Pérez-Cruz, M Alarcón-Tacuba, A Torres-Jaramillo, MA AlarcónRomero \& S López-Silva. 2009b. Cochlodinium polykrikoides and Gymnodinium catenatum in Bahía de Acapulco, Mexico (2005-2008). Harmful Algae News 40: 8-9.

Gárate-Lizárraga I, CJ Band-Schmidt, DJ López-Cortés \& JJ Bustillos-Guzmán. 2009c. Raphidophytes in Bahía de La Paz, Gulf of California. Harmful Algae News 40: 1-4.

Gárate-Lizárraga I, F García-Domínguez, B Pérez-Cruz \& JA Díaz-Ortíz. 2011. First record of Cochlodinium convolutum and C. helicoides (Gymnodiniales: Dinophyceae) in the Gulf of California. Revista de Biología Marina y Oceanografía 46: 495-498.

Gómez F. 2011. A checklist and classification of living dinoflagellates (Dinoflagellata, Alveolata). CICIMAR Oceánides 27(1): 65-140.

Gómez-Valdés J, JA Delgado \& JA Dwora. 2003. Overtides, compound tides, and tidal-residual current in Ensenada de la Paz lagoon, Baja California Sur, Mexico. Geofísica Internacional 42: 623-634.

Howard MDA, AC Jones, A Schnetzer, PD Countway, CR Tomas, RM Kudela, K Hayashi, P Chia \& D Caron. 2012. Quantitative real-time PCR for Cochlodinium fulvescens (DINOPHYCEAE), a harmful dinoflagellate from California coastal waters. Journal of Phycology 48: 384393.

Iwataki M, H Kawami \& K Matsuoka. 2007. Cochlodinium fulvescens sp. nov. (Gymnodiniales, Dinophyceae), a new chain forming unarmored dinoflagellate from Asian coasts. Phycological Research 55: 231-239.

Iwataki M, H Kawami, K Mizushima, CM Mikulski, GJ Doucette, JR Relox, AAnton, Y Fukuyo \& K Matsuoka. 2008. Phylogenetic relationships in the harmful dinoflagellate Cochlodinium polykrikoides (Gymnodiniales,
Dinophyceae) inferred from LSU rDNA sequences. Harmful Algae 7: 271-277.

Iwataki M, G Hansen, O Moestrup \& K Matsuoka. 2010. Ultrastructure of the harmful unarmored dinoflagellate Cochlodinium polykrikoides (Dinophyceae) with reference to the apical groove and flagellar apparatus. Journal of Eukaryotic Microbiology 57: 308-321.

Kofoid CA \& O Swezy. 1921. The free-living unarmored dinoflagellata. Memoirs of the University of California, $562 \mathrm{pp}$. University of California Press, Berkeley.

Kudela RM \& CJ Gobler. 2012. Harmful dinoflagellate blooms caused by Cochlodinium sp.: Global expansion and ecological strategies facilitating bloom formation. Harmful Algae 14: 71-86.

Matsuoka K, M Iwataki \& H Kawami. 2008. Morphology and taxonomy of chain-forming species of the genus Cochlodinium (Dinophyceae). Harmful Algae 7: 261-270.

Meave del Castillo ME, ME Zamudio-Reséndiz \& MA Castillo-Rivera. 2012. Riqueza fitoplanctónica de la Bahía de Acapulco y zona costera aledaña, Guerrero, México. Acta Botanica Mexicana 100: 405-487.

Morales-Blake A, C Cavazos-Guerra \& D HernándezBecerril. 2001. Unusual HABs in Manzanillo Bay, Colima, Mexico. Harmful Algae News 22: 6.

Morquecho-Escamilla ML \& R Alonso-Rodríguez. 2008. First record of Cochlodinium fulvescens in Mexican Pacific. Harmful Algae News 37: 5-6.

Munir S, T Naz, ZN Burhan, PJA Siddiqui, SL Morton. 2012. First report of the athecate, chain forming dinoflagellate Cochlodinium fulvescens (Gymnodiniales) from Pakistan. Pakistan Journal of Botany 44: 2129-2134.

Okolodkov YB \& I Gárate-Lizárraga. 2006. An annotated checklist of dinoflagellates (Dinophyceae) from the Mexican Pacific. Acta Botanica Mexicana 74: 1-154.

Utermöhl H. 1958. Zur Vervollkommung der quantitativen Phytoplankton Methodik. Mitteilungen der Internationale Vereinigung für Theoretische und Angewandte Limnologie 9: 1-38. 